guidance, many of the Delegates missed the delightful steamer-trip on the Danube from Passau to $\operatorname{Linz}$, from Linz to Vienna, and thence on to Budapesth.

The constitution of the Permanent English Committee is somewhat anomalous. We do not know how or when it is elected, but the following list taken from the official programme at Budapesth, shows that from a Committee supposed to consist of hygienists, those officially engaged in public health work are conspicuous by their absence. It would be invidious to discuss this list in detail; but the most casual survey will show that nearly one-half of those on the Committee have not, by published writings or by official position, indicated any interest in hygiene or demography. We are far from stating that original research or high social status should not receive ample representation; but it is a parody on English sanitation to pretend that on a Committee composed of 34 members, it is sufficiently represented by three members belonging to the public health service, even though those three are so eminent and so worthily representative as Drs. Thorne Thorne, Corfield, and Shirley Murphy.

$\begin{array}{ll}\text { Lord Wantage. } & \text { Dr. Vivian Poore. } \\ \text { Lord Baring. } & \text { Dr. E. Hart. } \\ \text { Sir K. V. Barrington. } & \text { Dr. W. Ogle. } \\ \text { Sir A. Blomfield. } & \text { Dr. J. F. W. Tatham, } \\ \text { Sir Douglas Galton. } & \text { Dr. Isambard Owen. } \\ \text { Sir Henry Roscoe. } & \text { Dr. Patrick Manson. } \\ \text { Sir N. Kingscote. } & \text { Prof. Victor Horsley. } \\ \text { Mr. F. Galton. } & \text { Dr. Armand Ruffer. } \\ \text { Sir H. S. King. } & \text { Dr. G. Thin. } \\ \text { Mr. E. Clarke. } & \text { Sir Joseph Fayrer. } \\ \text { Mr. W. R. E. Coles. } & \text { Surg. Gen. Cornish. } \\ \text { Colonel H. Pocock. } & \text { Prof. Lane Notter. } \\ \text { Mr. T. W. Cutler. } & \text { Surg. Lieut. Col. Pratt. } \\ \text { Mr. White Wallis. } & \text { Surg.-Gen. Marston. } \\ \text { Sir Joseph Lister. } & \text { Dr. Thorne Thorne. } \\ \text { Mr. Malcolm Morris. } & \text { Dr. Corfield. } \\ \text { Dr. C. E. Shelley. } & \text { Mr. Shirley Murphy. }\end{array}$

\section{THE CORRECTED DEATH RATE OF}

\section{METROPOLITAN DISTRICTS.}

IN another column we print an extract from $\mathrm{Mr}$. Shirley Murphy's annual report for 1892 , in which the factors of correction for age and sex distribution in the sanitary districts of London are given. We hope that in the remaining years of the present decade every Metropolitan health officer will use the factors here supplied, as it is only by this means that the correct comparisons of death-rates can be made, and the serious error which must arise in the comparison of crude death-rates be avoided.

The Registrar-General has published similar factors of correction for the 33 great towns, but we believe that this is the first time that such factors have been calculated for the equally important towns which are aggregated under the common name of London. London is greatly indebted to the Medical Officer of the County Council for having supplied a serious deficiency.

The factors now given show that the age distribution of all London districts is more favourable to a low mortality than that of England as a whole; hence in no instance is the factor below unity. Above this it varies from $\mathbf{I}^{\cdot} \mathbf{2} \mathbf{I} 7$ for St. Martin-in the-Fields, I'I 8 for Strand, I'I 5 for Hampstead and for the City of Londion, to $\mathrm{I}^{\circ} \mathrm{O}$. for Shoreditch and several other districts, and $x \cdot 03$ for Greenwich. Thus the corrected death-rate of Kensington is increased from 17.6 to 19.4 per 1,000 for the year 1892 ; that of Hampstead from $\mathrm{I}^{\circ} 3$ to $\mathrm{I} 4^{\circ} \cdot 2$, of St, George's Hanover Square from 17.5 to 19.3 ; while that of Greenwich is only increased from $19^{\prime} 2$ to $19^{\circ} 7$.

EPIDEMIC OF ENTERIC FEVER, TRACEABLE TO INFECTED ICE-CREAMS AND WATER - SUPPLY, AND ATTACKING OVER EIGHT HUTNDRED PERSONS.

By A. Campdell Munro, M.B., D.Sc., M.O.H. for the County of Renfrew.

ONE of the most notable and unfortunate experiences of 1893 was an epidemic of enteric fever, which swept over Mid-Renfrewshire in the latter half of the year. The elucidation of the causes of the epidemic was a matter of considerable difficulty.

During the first six months of the year there occurred within the landward (rural) portion of what I shall hereafter have occasion to refer to as "the Paisley Water Supply District"-in the part of that district under my own supervision-only the customary sporadic cases of enteric fever. In the month of June no cases of enteric fever were reported, and so matters continued during the three weeks ending I8th July. In the course of the next week 18 cases were notified, and in the week after 23 cases. The population of this landward district was only 7,500 ; with so small a population the number of cases notified indicated that we were face to face with an epidemic outburst of the disease. I learned about the same time that the disease was also epidemic in Paisley (estimated population 69,950), and in the Burgh of Johnstone (estimated population 9,900). Through the kindness of the sanitary officials of the Burgh of Paisley, I obtained the dates of sickening of cases occurring there at that time, and during the remainder of the epidemic. With the sanction of the Medical Officer of the Burgh of Johnstone, and with his hearty assistance and that of all the other medical men practising in the town (the Notification Act not being in force in Johnstone), I was able to obtain tolerably complete lists of the cases that occurred in the town from the beginning to the end of the epidemic. The circumstances of every case on these lists were minutely inquired into by the officers of the County Health Department, and the particulars duly recorded. In the first instance, and 
while my information was yet limited, careful inquiry was made into the source of milk-supply in each case, and when, as in some of the cases at the outset, any milk-supply appeared to have a relation to two or more cases, all the particulars connected with it were investigated, and the recent history of the personnel of the dairy was inquired into. It soon, however, became apparent that the epidemic had no relation whatever to milk supply. Nor could it be referred to a common origin in drainage. Paisley, Johnstone, and the half-dozen villages involved, were all separate and independent of one another in the matter of drainage.

There appeared, however, one clue to these earlier cases. A member of the family of an ice-cream dealer in Paisley sickened, on the $4^{\text {th }}$ of June, with what subsequent events clearly showed to have been an attack of enteric fever. The girl was in intimate contact with the icecrean business during most of the period of her illness. The existence of this case was unknown until the occurrence of another case in the same household was notified on the I8th July. The Paisley authorities acted with energy; the patients were removed to hospital and the parents to the reception-house on the 20 th July, and the whole premises were thoroughly disinfected. $\mathrm{F}$, the ice-cream dealer, thereafter attempted to resume business, but the story had become public property, he was mobbed, and had to give up business. It may be taken that the evil influence which subsequent events showed this business to have radiated, ceased from and after the 2 oth July. Notifications of cases (which had sickened some time before) now began to stream in upon the Paisley Sanitary Department. Taking successive series of $3 \mathrm{r}$ cases, the number of cases which were ascertained to have partaken of F.'s wares were $22,16,12,7,5,1 ; 63$ out of the first 186 had partaken of F.'s ice-creams. No further cases by any possibility traceable to $F$.'s business occurred.

Besides the shop in Paisley, F. had a ponycart, from which he sold ice-creams all over Paisley; and I found he frequently went round the village of Inkermann, about a mile out from Paisley, in the evenings. $\mathrm{He}$ was not in the habit of going to Johnstone, three miles distant from Paisley, there being three permanently established ice-cream shops there, but I ascertained that he had been selling ice-creams in Johnstone on the ${ }_{5}$ th July, the high day of the Johnstone "Fair." I presently found that of the first fifteen cases which occurred at Inkermann, there were reasonably traceable to the ingestion of F.'s icecreams no fewer than $\mathrm{I} x$.

Very soon, however, I found that F.'s ices carried us but a little way in accounting for the cases which cropped up. Indeed, through the whole epidemic which followed in the Burgh of Johnstone-where it rose to an alarming height in the week ending July $25^{\text {th }}$-and in the landward district, I was only able to obtain a suggestion of ice-cream ingestion in 24 cases. In many cases it was ascertained that ice-creams had been procured from one or other of the Johnstone shops, and we applied ourselves to the endeavour to trace any subterranean connection between these and F. I was able to satisfy myself that any such connection was practically impossible. I made the most careful inquiry into the health of the persons employed in connection with each ice-cream shop, without finding any ground for suspicion.

Yet the epidemic went steadily on all over the district originally attacked. The ice-cream theory no longer subserved. The ice-cream influence practically ceased on the zoth of July. The epidemic was not maintained by the occurrence of secondary cases; it will be seen by the table appended that the percentage of secondary cases was relatively small. It became necessary to reconsider the wbole situation. I had already observed that the epidemic prevalence of the disease was confined to the district supplied from the Paisley Water Commissioners' mains, - that district including Paisley itself, the Burgh of Johnstone, the villages of Elderslie, Linwood, Blackstone, and Inkermann, and the environs of Paisley and Johnstone. The disease was but slightly prevalent in the village of Kilbarchan, into which the Paisley water had just been introduced.* I could ascertain no other operative circumstances common to the district. But it involved a serious responsibility to inculpate the water supplied by the Paisley Water Commissioners, and I hoped each week to see an abatement of the disease. I had handbills posted over the district under my own control, advising the people to boil "all drinking water and milk" before use; I added the word "milk" with a view to prevent an absolute scare arising with respect to the water supply. I now placed myself in communication with the Water Commissioners, and a closer control was exercised over the management of the water-works. At this time the medical officer of Paisley, without any consultation with me, and quite independently, made a report which, it was understood, inculpated the water-supply, to the local authority for the burgh. This report was promptly suppressed by the local authority! Immediately thereafter it became my duty to report to the monthly meeting of the District Committees of the County Council with respect to the circumstances of the epidemic. Following upon this report, a sub-committee had a conference with the Paisley Water Commissioners, at which the Commissioners agreed to appoint an engineer to examine the works, and a bacteriologist to inquire into the quality of the water. It was also stated that instructions had been given that the water from one of the reser-

* Here the water, tasting unpleasantly "of the pipes," was as yet but little in request for drinking purposes. 
voirs, to which I had directed attention, should be entirely turned off (October roth). It appears, however, that, allowing for the period of incubation of the disease, the epidemic influence had by this time practically disappeared, the cold rainy season having set in.

Such is a condensed history of the epidemic. It remains for me to present an analysis of the figures. . . . . I addressed myself to institute a systematic comparison of the number of cases of enteric fever occurring week by week during the epidemic period, in the district outside of the Paisley water area, with the number of cases occurring within that area. For this purpose $I$ in the first place selected for examination a sufficiently large area to enable me to avoid the errors apt to arise from accidental causes, in dealing with small areas or populations. This area I divided into two sections, according to its source of water supply. 859 cases occurred amongst a population of 86,000 within the Paisley Water area, while only 236 occurred during the same period amidst a population of 380,000 outside of that area. Otherwise put, the case-incidence within the Paisley Water Supply District was $\mathrm{I}$ in every IOI persons, while in the outside area there occurred only I case in every $\mathrm{I}, 6 \mathrm{r} \circ$ persons. No single section of the district outside approached the epidemicity attaching to the least involved section of the district within.

With the view of checking these results, I isolated the landward (rural) portion of the county, the portion under my own immediate purview, and divided it according as it derived its water supply from the Paisley Water Commissioners' mains or from other sources. The results are approximately the same as in the first case. . . . There occurred 1 case in every 52 persons within the special area, as compared with $I$ in every $I, 484$ persons in the area outside the Water Supply District.

It appears to me impossible to resist the conclusion that, apart from the cases arising in connection with the ice-cream infection, * this epidemic had its origin and source in the water-supply.

Reference was made at the time of the epidemic to the varying incidence of the disease within the Paisley Water Supply District. Both Johnstone and the landward district suffered much more severely than Paisley. This does not affect the main question as to the origin and cause of the epidemic, but it raises interesting points of inquiry, to which I am only able to offer provisional replies. The small village of Inkermann (pop. 560 ), for instance, suffered exceptionally from the disease, 42 cases having occurred there; but of these 42 cases 10 were found to have partaken of F.'s ice-

* In all, there occurred only 86 cases in any way traceable to $\mathbf{F}$.'s ice-creams; deducting these, the case-rate within the Paisley water area was 8.9 per thousand, or a mean of one case in every II 3 persons resident in the district. creams, and $\mathrm{I} 3$ cases, although resident in Inkermann, that is, spending their nights and their Sundays there, were working in Paisley or the neighbourhood, mostly in the cotton mills, and were away from the village from about 5.30 in the morning till $7.3^{\circ}$ in the evening. Sickening in Inkermann, they are, of course, set down as Inkermann cases. This furnishes an illustration of the fallacies attaching to deductions derived from small numbers, which may be largely falsified through accidental circumstances. - Assuming that the disease was water-spread, one important circumstance must be taken into consideration, that is, the quality of the water at the "dead ends" of water-mains. It is well known that the water at and in the vicinity of these dead ends, especially dead ends at the lower levels, becomes a locus for the deposition of particulate matter; and that when these dead ends are tapped periodically (as they ought to be, but seldom are), the water drawn from them is found to be exceedingly dirty. It is a legitimate suggestion that water drawn from a dead-ended main will include a much larger amount of bacterial life than water which is circulating rapidly in mains with a continuous flow. Now, in Paisley, from its size and the greatness of its manufacturing industries, there is a very large consumption and a rapid circulation of water daily. I believe it was observed in Paisley that the cases there grouped themselves largely in streets supplied with water from mains with dead ends. We have this distinction, then, between Paisley and the rest of the Water District, - that the water in Paisley is for the most part in rapid circulation and in continuous flow through a series of interlacing pipes. In Johnstone and the landward district the water supply is, for the most part, from mains with a sluggish flow and with a large number of dead ends.* These, however, are in the meantime merely hypothetical considerations.

It is necessary now to consider the circumstances and condition of the Paisley water supply. The Paisley Water Works are of some magnitude. They include impounding reservoirs upon the Rye in Ayrshire, at Rowbank, and at Stanley, above Paisley. The Rye reservoirs receive a water which is somewhat peaty, but which is in no way subject to contamination. The intermediate reservoir at Rowbank cannot be dismissed so summarily. I may say at once that no case of enteric fever had been notified from within the catchment area of this reservoir in the course of the twelve months preceding the epidemic, nor did I learn of the existence of any such case. The following is an extract from a report on the subject by the consulting engineers :- "There are I 2 farm steadings within the catchment area, and we person-

\footnotetext{
* I subsequently learnt that, indifferent as the filtration had been at the Stanley Filters above Paisley, matters had been much worse at the Craigenfeoch Filters above Johnstone.
} 
ally examined each one of them to ascertain how the foul water proceeding from the steadings and dwelling houses is disposed of. In every case but one the water from the byres and from the middens, and the slops from the dwelling houses, are disposed of on meadows or on the grass land, and there is no direct communication from them by pipes or open channel to the stream. At several of the larger farms the foul water is led on to meadows for irrigation, and great care is taken by the farmers that it is well spread over the grass for the purpose of getting the full advantage of its fertilising qualities. Irrigation on grass land is recognised as the most effective mode of purifying sewage or other foul water, and we are of opinion that in the case of these farms any foul water is rendered comparatively innocuous before it reaches the streams where it is subjected to the further purifying influence of the running water before it reaches the reservoir. There is one farm, Tower of Auchenbothie, which is not in a good state. The midden is close to a running stream, and foul water is liable to be washed into the stream in wet weather. It will be necessary to intercept this foul water, and to conduct it into a proper channel to the meadow for irrigation, and means should be taken to prevent the drainage from the midden reaching the stream." The engineers put matters very gently. The farm steading last referred to practically drained into the reservoir.

On the occasion of my first visit to the reservoir about a month after the beginning of the epidemic, I found that there had existed close to the margin of the water, up till the 6th July, an inhabited farmhouse, the drainage or soakage from which could only escape into the reservoir. The steading itself, however, was situated on the other side of the bye-pass channel.

At South Castlewalls farm I found that one little tributary of the Row carried off the sewage of the house and farm, emerging between the dungstead and the privy. The flow of this streamlet may be distributed by broad irrigation, or may join the main stream by a cut.

When the question of the water-supply had evolved as a matter of public discussion, the Paisley Water Commissioners instructed Professor Percy Frankland, of University College, Dundee, to visit the works, and institute investiyations as to the quality of the water. The course of events, as subsequently revealed, showed that at the time of Dr. Frankland's visit the epidemic was already rapidly declining. The following is Dr. Frankland's report :-

\section{University College, Dundee, October $28 \mathrm{~h}, 1893$}

PaISLEY WATER.

I have herewith to report to you further on the bacteriological and other aspects of the examination which I have made of a portion of the Paisley water supply, more especially as to its possible connection with the outbreak of typhoid fever, which, as I understand, has taken place in that town. In view of such a suspicion I deemed it advisable to make a very careful search for the typhoid bacillus in the two samples of, unfiltered water which I collected from Rowbank and Camphill respectively. To this end the two samples in question were submitted to a special process of cultivation, which, whilst fostering the growth and multi. plication of the typhoid bacilli and of a few other forms, is inimical to the majority of the bacteria present in natural waters. This special method of examination revealed the presence in both waters of certain bacteria possessing a strong superficial resemblance to the typhoid bacillus, but which on closer study proved to be distinguished from the latter in certain important fearures, and 10 bear a closer resemblance to the so-called Bacillus Coli Communis, which is normally present in the foces of man and the higher animals. I should point out, however, that much importarice cannot be attributed to such a negative result, for the chance of finding typhoid bacilli which had gained access to such large bodies of water would in any case be exceedingly remote. Only under the rarest and most excep ional circumstences is it to be anticipated that the morbific matter should be discovered by direct bacteriological examination. The great value of the bacteriological method of inquiry, on the other hand, lies in its enabling us to furnish an answer to the question-If con. tamination of the water supply with morbific matter should take place, is there any adequate barrier to prevent its dis. tribution to the consumer? To this question the results of the examination which $I$ have made furnish an answer in no uncertain terms. Assuming typhoidal excrements to gain access to the Rowbank Reservoir, the obstacles which the pathogenic bacteria would encounter before they could reach the consumer are two in number-(I) prolonged storage in the reservoir; (2) sand filtration. As regards the obstacle of storage, the bacteriological examination of the water in the reservoir revealed the presence of a large number of bacteria, showing that removal of micro+organisms by subsidence was not taking place to the extent that I should have anticipated, whilst the fact that the water is so highly impregnated with organic matter, and that bacteria which are at any rate closely allied to the typhoid bacilli were discovered, would indicate that the conditions in the reservoir at the time of my examination were at any rate not palpally hostile to the requirements of the typhoid bacilli. If, then, any typhoid bacilli imported into the reservoir should pass forward to the filter works, what probability is there that they would be arrested there? From my examination of the filtrate, which was being yielded by each individual bed, both at the Johnstone and the Staneley High Level works, it is obvious that at any rate several of these beds were discharging their duties in a very indifferent manner. [To illustrate this point, Professor Frankland cites some of the results which he has quite recently obtained by sand filtration at the London Waterworks.] That the results at Paisley should be so markedly inferior to those obtained at the London works is not surprising when the difference in the mode of filtration at the two places is taken into consideration. Thus, as I have already pointed out, several of the filters were visibly leaking through their retaining walls into the filter wells, whilst the rate of flitration is, from the figures with which you have supplied me, greatly in excess at Paisley of that which is employed in London. In this connection I may point out that whilst, as I understand, the rate of filtration pursued at the Paisley works is about five gallons per square foot per hour, the rates of filtration as carried out at the London works are, according to the most recent returns, as recorded in the following table :-

Average Rate of Filtration by London Water Companies, EXPRessed iN Gallons PER SQUart FOOT PER HOUR.

Chelsea Company

East London Company $\quad \ldots \quad \ldots \quad 14$ gallons.

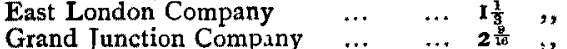

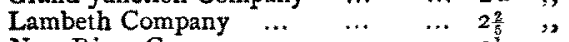

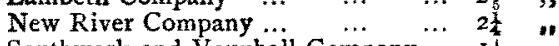

Southwark and Vauxhall Company ... I I $\frac{1}{3}$ ",

West Middlesex Company ... ... I , 
Thus, whilst the Paisley filters undoubtedly offer a considerable barrier to the passage of bacteria, the results clearly show that this barrier is by no means what it should be ; and I am acquainted with instances in which filtration, similarly demonst rated to be inefficient by bacteri.,logical examination, was attended by outbreaks of enteric fever, which ceased when the filtration was remedied. The question further arises as to the possibility of morbific matter gaining access to the Paisley reservoirs. In this connection I can only speak of the portion of the Rowbank gathering ground, which I inspected in company with $\mathrm{Mr}$. Reid, and where we found the arrangements for refuse disposal of one farm at any rate presenting a constant menace to the safety of the water in the reservoir. Of the possibility of morbific matter gaining an entrance there can be no doubt, although there is no evidence that the water has received such materials. On the other hand, the unsatisfactory state of the filters show how serious would be the situation if such possible contamination of the reservoirs were at any time to take place. I am of opinion, therefore, that whether the present outbreak is or is not connected with the water supply, prompt measures should be adopted to both abolish the possibility of contamination on the gathering ground as well as to secure the maximum purification by improved fltration.

\section{ON AN OUTBREAK OF ANOMALOUS ILLNESS CHARACTERISED CHIEFLY BY BRONCHO-PNEUMONIA AND SORE- THROAT IN THE PARISH OF LAX. FIELD SUFFOLK.}

By R. Bruce Low, M.D., Medical Inspector to the Local Government Board.

[Dr. Low, after giving a detailed account of this interesting outbreak, gives the following compara. tive statement of the points of resemblance to a somewhat similar outbreak at Raunds, in Northamptonshire in $189 \mathrm{r}$, followed by a summary of the evidence.]

\section{Considerations as to the Nature of the LaXfikidD Malady.}

\section{Its similarity to that which prevailed at Raunds in I89r.}

Mention has been made of a somewhat similar epidemic which occurred at Raunds in the early part of 1891 . By way of comparing the two outbreaks, and with a view to ascertaining whether they were manifestations of one and the same disease, the leading features observed in the two outbreaks are placed in parallel columns.

ThE Raunds OUtBreak.

Vomiting, drowsiness, fever, cough, sore throat. Diarrhcea in about one-third of the cases. Herpes of the lips in several cases. Jaun. dice in some cases.

Symptoms consistent with meningitis, e.g., delirium, fits of screaming, squinting, retraction of the head, convulsions and coma in fatal cases.
The Raunds OUtbreak.

Enlargement of parotid and cervical glands. Preva. lence of sore throat in adults of invaded household.

Lung mischief varying from mild bronchitis to acute pneumonia.

Profuse sweating and epistaxis towards the termination of acute symptoms

Only 5 cases out of 155 attacked had a red, scarla. tina-like rash, followed by desquamation.

The disease mainly attacked young children, especially those under so years.

Nine out of the total Io deaths from the malady were in children under 2 years of age.

The average duration of the acute symptoms was from Io to 12 days, but mild cases las ed only 5 days or so.

Ear discharges developed in several cases.

The epidemic period com prised 5 weeks.

It will be noticed that in the main clinical features of the two outbreaks there is a close resemblance. In the Raunds outbreak there was in certain respects greater severity of the symptoms.

\section{Summary of Evidence.}

In summing up the evidence as to the nature of the malady recently prevalent at Laxfield, it is not to be denied that, in many particulars, the epidemic resembled some of the more recentlyobserved outbreaks of influenza. The manifestations of this disease during the last four years appear to have taken several different forms; and unless observers have fallen into the error of confounding influenza wlth some other malady or maladies, the disease would seem to undergo considerable changes in type. The fact that the Laxfield outbreak was almost altogether limited to children is in itself peculiar-pointing rather in the direction of epidemic cerebro-spinal meningitis* than of influenza. The suggestion, however, arises, and this has already been discussed by some writers, as to whether, after all, epidemic influenza may not be a manifestation, modification, or, so to speak, a "sport" of cerebro-spinal fever.

During the last four years the medical periodicals have furnished cases in which serious nervous symptoms have accompanied influenza, or followed it, e.g." " tetaniform conı ulsions," "myelitis," \&c.. There have also occurred of late years, associated with influenza epidemics, groups of cases having meningeal symptoms, and in instances where death

* In the great epidemic on the Lower Vistula of 1865 , out of a total of 347 deaths at all ages, the deaths under fourteen years of age numbered 318. - Annual Report of the Medical Officer to the Privy Counci], 1865, p. 270. 